\section{Child and adolescent labor and smoking: a cross-sectional study in southern Brazil}

\author{
A associação entre trabalho de crianças e \\ adolescentes e tabagismo: um estudo \\ transversal no Sul do Brasil
}

Marinel Mór Dall'Agnol 1,2
Anaclaudia Gastal Fassa 2
Luiz Augusto Facchini 2

\title{
Introduction
}

1 Departamento de Saúde da Comunidade, Universidade Federal de Santa Maria, Santa Maria, Brasil.

2 Programa de Pós-graduação em Epidemiologia, Universidade Federal de Pelotas, Pelotas, Brasil.

Correspondence M. M. Dall'Agnol Departamento de Saúde da Comunidade, Universidade Federal de Santa Maria. Rua Roraima 1000, prédio 26 , sala 1241, Santa Maria, RS 97105-900, Brasil.

marinelmd@terra.com.br

\begin{abstract}
This cross-sectional study assessed the association between smoking and child and adolescent labor among 3,269 individuals 10 to 17 years of age in Pelotas, Rio Grande do Sul State, in southern Brazil (excluding higher income census tracts) in 1998. Adjusted hierarchical analysis was performed using Poisson regression. Prevalence of child labor was 13.8\%. Current smoking prevalence was $6.3 \%$ in the sample as a whole $115.7 \%$ among working versus $3.4 \%$ among non-working children). In the multivariate analysis, smoking was significantly associated with child labor, with a prevalence ratio of 1.75 (95\% CI: 1.30-2.36). Smoking was also associated with family characteristics (lower maternal schooling, mother currently without husband/partner, household members with alcohol or drug problems, single mother, and history of serious injuries), and the children's characteristics (age greater than 16 years, inadequate school performance, and externalizing behavior). The findings point to smoking as one of the harmful consequences of child labor and suggest the workplace as an appropriate target for smoking prevention.
\end{abstract}

Child Labor; Smoking; Child; Adolescent
Smoking by children and adolescents is a serious public health problem. Age at tobacco addiction has been decreasing 1 , while one-fourth of young adult smokers tried their first cigarette before 10 years of age 2 and the vast majority ( $80 \%$ ) began smoking before they reached 18 years ${ }^{3}$. The earlier individuals begin smoking, the higher the odds of developing nicotine addiction 3 . If the current trend persists, in the future tobacco will kill 250 million of today's children and adolescents from smoking-related diseases like cancer, emphysema, and myocardial infarction and other cardiovascular diseases 3 and will have immediate effects on youth, like respiratory problems such as cough and wheezing, a reduction in growth rate and intensity and lung function 4,5, and reduced histamine with an increase in erectile dysfunction 2 .

Among adolescents, smoking prevalence rates have remained stable or increased $2,6,7$, thus contrasting with the decline among adults (except for women in low and middle income countries) 3,8 . In the decade around the turn of the millennium, national surveys in Canada and the United States showed that from $17 \%$ to $36 \%$ of adolescents smoked 9,10. Among schoolchildren, smoking prevalence rates showed major differences among the countries assessed by Global Youth Tobacco Surveillance in the 13 to 15 -year bracket (GYTS, 2000-2007), varying from $1 \%$ to 
$39.6 \%$ (for cigarette consumption) 2,11. In Brazil, according to this same survey, prevalence rates varied from $6.2 \%$ to $17.7 \%$, with the latter rate found in Porto Alegre, in the southernmost State of Rio Grande do Sul, in 2002 6,12,13.

Cigarette addiction in teens is facilitated by easy access and low prices, peer pressure, approval of the habit by friends, parents, and siblings, and the notion that smoking brings popularity. Girls have the added appeal of body aesthetics, due to the belief that smoking is associated with weight loss 2 .

Smoking is more common in males, but in $60 \%$ of the countries assessed by the GYTS this difference was not significant, and in $14 \%$ of the countries more girls than boys smoked ${ }^{2}$. In addition, the difference in smoking rates between boys and girls is less than between adult men and women, suggesting that smoking prevalence among girls is increasing ${ }^{3}$. In the State capitals in the South of Brazil, smoking prevalence is higher among girls (e.g., $21.6 \%$ in girls and $12.9 \%$ in boys, in Porto Alegre) 12.

Child and adolescent smoking was directly associated with age $7,12,14,15,16,17,18$, inadequate school performance $15,18,19$, presence of smokers among siblings or friends 15,20,21,22, absence of the biological father, poor relationship with the mother, family conflicts, separated/divorced parents 18 , physical beating by parents, bad influences, involvement in fights, running away from home, and alcohol consumption 18,23. Aggressive behavior, feelings of sadness and loneliness and insomnia in both sexes, and introverted behavior in girls also increase the risk of smoking in children and adolescents 16,24. Lower maternal schooling was a risk factor for childhood smoking 22,23, while the same was not true of the head-of-household's schooling 25 . In some studies, family income and current social class were not associated with child and adolescent smoking $19,23,25$, but there was an association with low family income at birth and persistent poverty from birth into early adulthood 7 .

There is a major concern that child labor may generate a pseudomaturity syndrome, stimulating behaviors ascribed to the adult world, including smoking 26. However, few studies have investigated the influence of child labor on smoking. Most of the publications approach possible interventions for smoking cessation among young workers. The few existing studies are limited to students in developed countries and fail to assess important confounding factors. Young adults in workplaces with large concentrations of smokers tend to increase their cigarette consumption, while there is a decrease among older workers 27,28. Working students (both fulltime and part-time) show high smoking rates and high consumption of alcoholic beverages and illicit drugs, with at least double the prevalence of 12-to-17-year-olds that are only studying, not working 14,16,29,30. Heavy consumption of these substances ( $\geq 20$ cigarettes per day in the case of smoking) is much more frequent among fulltime workers (odds ratio $-\mathrm{OR}=8.9$ ) 16 .

Considering the large contingent of workers from 5 to 17 years of age in Brazil (5.4 million) 31 and in the world (317 million) 32 , the current article focuses on the association between child labor and smoking, using data from a larger study assessing work from 6 to 17 years of age and its impact on health, in the city of Pelotas. The investigation into the role of child labor in the determination of smoking could shed light on negative repercussions of early work on the behavior of children and adolescents, besides identifying ways to prevent this harmful habit, considering in this case adolescents working under legal conditions.

\section{Methodology}

The study adopted a cross-sectional design, assessing individuals 10 to 17 years of age living in the urban area of Pelotas. Data were collected during home interviews from January to August 1998. The sample excluded the highest income census tracts, where child labor is infrequent. Sample selection used a single-stage cluster technique. The municipality's urban census tracts were stratified by head-of-household's income, excluding those in which more than $1.5 \%$ of the heads-of-households earned more than 20 times the legal minimum wage (i.e., a monthly income greater than R\$2,400.00, or US\$2,100.00) 33 . Based on this criterion, 175 tracts $(68 \%)$ were eligible, and of these, the 22 tracts needed to complete the sample were selected by simple random sampling (13\% of the eligible tracts). In the selected tracts, all the households were visited, attempting to interview all the individuals in the target age bracket, except for those who were unable to answer the questionnaire or were institutionalized.

The sample of 3,269 interviewees allows analyzing the association between child labor and smoking. Prevalence of work among children and adolescents was $14 \%$, and prevalence of smoking among non-workers was $6.5 \%$. Thus, this sample provides a statistical power of $80 \%$ to identify relative risks of 1.6 with a $95 \%$ confidence level.

Three instruments were used. The family questionnaire was answered by the housewife (or in her absence by the head-of-household) and 
covered socio-demographic information and problems with household members. The children's questionnaire was answered by the children themselves, covering their demographic, occupational, and smoking characteristics, structured for this study. The Child Behavior Checklist (CBCL) 34 was used to measure child behavior, since it applies to this age bracket and had been validated in Brazil, showing a sensitivity of $80.4 \%$, specificity of $66.7 \%$, and total error classification rate of $20.4 \% 35$. The questions were answered by the child's mother, identifying the frequency of the child's attitudes in the previous six months. The answers are converted into $\mathrm{T}$ scores and classified as clinical when the $\mathrm{T}$ score is greater than 6034 . The grouping of some questions classifies the behavior in two dimensions: internalizing, obtained from the scales on withdrawal, somatic complaints, and anxiety, and externalizing, consisting of the scales for delinquent and aggressive behavior.

The dependent variable was smoking, defining smokers as those that reported having smoked one or more cigarettes in the 30 days prior to the interview. Child labor at the time of the interview was defined as the main target variable, defined as any activities that contributed to the production of goods or services, including unpaid activities and excluding household chores in the child's own residence. Productive activity was defined by asking the children to describe the kind of work they did, their tasks, and the company's name. This information was classified as non-domestic services (tire repair, home appliance repair, receptionist, office boy, leaflet delivery/distribution, sports assistant, etc.), domestic services (babysitter, maid, janitor, housekeeper, etc.), commerce (bar helper, home delivery, street vendor, produce market helper, etc.), construction and manufacturing (carpenter's or baker's helper, etc.), marginal activities (watching parked cars, begging, garbage-picking, etc.), and agriculture/livestock. Age was recorded as complete years. The study covered the age bracket from 10 to 17 years, but the individuals were all referred to as "children" to simplify and standardize this article's wording. The age cutoff within the overall group was 16 years, which is the minimum legal age for working in Brazil. The child's school performance was measured as adequacy of school grade for age, calculated on the basis of the number of passing school years and age in complete years. Schooling was considered adequate when an 8-year-old had finished the first grade, a 9-year-old the second grade, and so on up through the grades. Thus, grade-for-age was considered inadequate when there was a grade delay, indicating that the child had failed one or more grades, failed to enroll, or dropped out. Family income was the sum of the income of all the household residents during the month prior to the interview, including the children's income when they performed paid work. The housewife's schooling was measured in complete years (passing). The occurrence of family problems was measured by asking the housewife if in the previous 12 months any of the household residents had separated from the spouse, become a single mother, had problems with alcohol or drugs, suffered a serious accident, had some illness that required constant care, died, become unemployed, or gone into major debt or bankruptcy.

Data collection was done by 22 medical and nursing students, who conducted the interviews in pairs. Four visits were made on different days and at different times to locate missed residents. After these attempts, if the child had not been found or refused to participate in the study, his or her age and occupational status were verified with the housewife or another adult who was at home.

The analysis used Stata 9.0 (Stata Corp., College Station, USA). Description of the population used measures of central trend and dispersion for the continuous quantitative variables and proportions for the qualitative variables. Associations between the various exposures and smoking were evaluated using Poisson regression with bivariate and multivariate analysis with robust variance, measuring the effects with the prevalence rates (PR) and the 95\% confidence intervals $(95 \% \mathrm{CI})$. The use of robust variance aimed to correct the dispersion resulting from the analysis of dichotomous outcomes with Poisson, taking into account the design effect for cluster samples of individuals. The multivariate analysis was hierarchical according to the theoretical model. The variables that showed an association with alpha error less than $20 \%$ were included in the multivariate analysis to control for confounding. After this adjustment, associations with $p$-values $\leq 5 \%$ were considered significant.

The research project was approved by the Institutional Review Board of the Federal University in Pelotas, and was considered to involve minimal risk for participants. The interviewers requested verbal consent from the informant, guaranteeing the right to refusal and confidentiality.

\section{Findings}

Smoking prevalence was $6.3 \%$, and nearly one third of smokers (31\%) consumed more than 10 cigarettes per day, with a median of 6 cigarettes per day. Prevalence of child labor was $13.8 \%$ ( $n=$ 
$451)$, and these children worked in commerce (34\%), non-domestic services (25\%), domestic services (20\%), construction (13\%), manufacturing (5\%), marginal activities (2\%), and agriculture/livestock (1\%). The sample was distributed homogeneously between boys and girls, threefourths belonged to the younger age bracket (10 to 15 years), and more than half of the children had inadequate grade-for-age in school (55\%). Child behavior problems were present in more than one-fifth of the sample: $26 \%$ displayed internalizing behavior and $22 \%$ externalizing behavior (Table 1).

There was no association between gender and childhood smoking in the crude analysis. The other child-specific characteristics (Table 1) were associated with smoking at the proposed significance level to control for confounding in the multivariate analysis. Smoking prevalence rates were higher among working children (12.9\%), older children $(15.7 \%)$, those with inadequate grade- for-age $(10.4 \%)$, and those with behavioral problems $(7.1 \%$ for introverted behavior and $9.5 \%$ for aggressive/delinquent behavior) (Table 1).

Importantly, $6.2 \%$ had not been attending school in the previous year, and among these, smoking prevalence was much higher (34.5\%), increasing the likelihood of smoking by nearly eightfold ( $\mathrm{PR}=7.88$, 95\%CI: 6.13-10.14). However, this variable was not included in the multivariate analysis, since adequate grade-for-age was chosen as the school performance indicator.

Table 2 shows the distribution of family characteristics. Monthly family income was greater than six times the monthly minimum wage (R\$ 720.00 , or U\$ 630.00) for one-third of the sample, and $10 \%$ earned less than one minimum wage (R\$ 120.00 , or U\$ $105.00 /$ month). Median schooling in the housewives was 6 years; $21 \%$ had finished 9 or more years of schooling, and $6.5 \%$, had not finished the first grade. The majority of the housewives were married or in com-

Table 1

Sample distribution *, childhood smoking prevalence rates, and crude prevalence ratios (PR) according to the children's characteristics. Pelotas, Rio Grande do Sul State, Brazil $(\mathrm{N}=3,269)$.

\begin{tabular}{|c|c|c|c|c|c|}
\hline Characteristics & $\mathbf{n}$ & $\%$ & $\begin{array}{c}\text { Smoking } \\
\text { prevalence (\%) }\end{array}$ & Crude PR $(95 \% \mathrm{Cl})$ & p-value \\
\hline \multicolumn{6}{|c|}{ Currently working } \\
\hline Yes & 451 & 13.8 & 12.9 & $2.49(1.86-3.31)$ & $<0.001$ \\
\hline No & 2,815 & 86.2 & 5.2 & 1.00 & \\
\hline \multicolumn{6}{|l|}{ Gender } \\
\hline Male & 1,665 & 51.0 & 6.7 & $0.85(0.65-1.16)$ & 0.25 \\
\hline Female & 1,601 & 49.0 & 5.8 & 1.00 & \\
\hline \multicolumn{6}{|l|}{ Age (years) } \\
\hline $10-15$ & 2,513 & 76.9 & 3.4 & 1.00 & \\
\hline $16-17$ & 753 & 23.1 & 15.7 & $4.58(3.51-5.97)$ & $<0.001$ \\
\hline \multicolumn{6}{|c|}{ Adequate grade-for-age } \\
\hline Yes & 1,465 & 45.1 & 1.2 & 1.00 & \\
\hline No & 1,786 & 54.9 & 10.4 & $8.97(5.49-14.68)$ & $<0.001$ \\
\hline \multicolumn{6}{|c|}{ Internalizing behavior ** } \\
\hline Yes & 820 & 26.1 & 7.1 & $1.25(0.93-1.69)$ & 0.14 \\
\hline No & 2,317 & 73.9 & 5.7 & 1.00 & \\
\hline \multicolumn{6}{|c|}{ Externalizing behavior ** } \\
\hline Yes & 686 & 21.9 & 9.5 & $1.87(1.40-2.50)$ & $<0.001$ \\
\hline No & 2,451 & 78.1 & 5.1 & 1.00 & \\
\hline \multicolumn{6}{|c|}{ 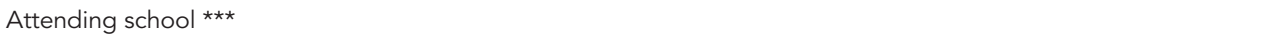 } \\
\hline Yes & 3,062 & 93.8 & 4.4 & 1.00 & \\
\hline No & 203 & 6.2 & 34.5 & $7.88(6.13-10.14)$ & $<0.001$ \\
\hline
\end{tabular}

95\% Cl: 95\% confidence interval.

* Up to $1 \%$ unknown, except for behavioral problems (4\%);

** Child Behavior Checklist (CBCL), clinical: T score > 60;

*** During previous year. 
Sample distribution *, childhood smoking prevalence, and crude prevalence ratios (PR) according to family characteristics. Pelotas, Rio Grande do Sul State, Brazil $(\mathrm{N}=3,269)$.

\begin{tabular}{|c|c|c|c|c|c|}
\hline Characteristics & $\mathrm{n}$ & $\%$ & $\begin{array}{l}\text { Childhood } \\
\text { smoking } \\
\text { prevalence (\%) }\end{array}$ & $\begin{array}{c}\text { Crude PR } \\
(95 \% \mathrm{Cl})\end{array}$ & p-value \\
\hline 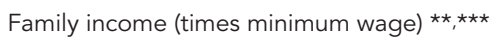 & & & & & $0.011 \# \# \#$ \\
\hline$\leq 1.0$ & 297 & 10.4 & 8.8 & 1.00 & \\
\hline $1.1-2.0$ & 351 & 12.4 & 7.1 & $0.81(0.48-1.38)$ & 0.48 \\
\hline 2.1-4.0 & 835 & 29.3 & 5.9 & $0.67(0.42-1.06)$ & 0.09 \\
\hline $4.1-6.0$ & 516 & 18.1 & 5.8 & $0.66(0.40-1.10)$ & 0.11 \\
\hline$>6.0$ & 849 & 29.8 & 4.7 & $0.54(0.33-0.87)$ & 0.01 \\
\hline Housewife's schooling (years) \# & & & & & $<0.001 \# \# \#$ \\
\hline None & 206 & 6.5 & 9.2 & 1.00 & \\
\hline $1-4$ & 996 & 31.2 & 7.1 & $0.79(0.51-1.23)$ & 0.29 \\
\hline $5-8$ & 1,326 & 41.5 & 6.1 & $0.68(0.44-1.05)$ & 0.08 \\
\hline$\geq 9$ & 666 & 20.8 & 4.2 & $0.53(0.32-0.88)$ & 0.01 \\
\hline \multicolumn{6}{|l|}{ Housewife's marital status } \\
\hline With husband/partner & 2,423 & 75.8 & 5.3 & 1.00 & \\
\hline Without husband/partner & 772 & 24.2 & 9.2 & $1.74(1.31-2.30)$ & $<0.001$ \\
\hline \multicolumn{6}{|l|}{ Family problems in previous year \#\# } \\
\hline \multicolumn{6}{|l|}{ Unemployment } \\
\hline Yes & 588 & 18.4 & 8.8 & $1.56(1.16-2.12)$ & 0.004 \\
\hline No & 2,606 & 81.6 & 5.6 & 1.00 & \\
\hline \multicolumn{6}{|l|}{ Alcohol or drugs } \\
\hline Yes & 305 & 9.6 & 12.1 & $2.16(1.54-3.03)$ & $<0.001$ \\
\hline No & 2,888 & 90.4 & 5.6 & 1.00 & \\
\hline \multicolumn{6}{|l|}{ Chronically ill family member } \\
\hline Yes & 286 & 8.9 & 7.0 & $1.13(0.72-1.77)$ & 0.6 \\
\hline No & 2,908 & 91.1 & 6.2 & 1.00 & \\
\hline \multicolumn{6}{|l|}{ Separation/Divorce } \\
\hline Yes & 201 & 6.3 & 10.6 & $1.75(1.14-2.70)$ & 0.01 \\
\hline No & 2,993 & 93.7 & 6.0 & 1.00 & \\
\hline \multicolumn{6}{|l|}{ Death } \\
\hline Yes & 192 & 6.0 & 6.3 & $1.00(0.57-1.77)$ & 1.0 \\
\hline No & 3,002 & 94.0 & 6.3 & 1.00 & \\
\hline \multicolumn{6}{|l|}{ Major indebtedness or bankruptcy } \\
\hline Yes & 165 & 5.2 & 9.7 & $1.61(0.99-2.61)$ & 0.057 \\
\hline No & 3,029 & 94.8 & 6.0 & 1.00 & \\
\hline \multicolumn{6}{|l|}{ Single mother } \\
\hline Yes & 96 & 3.0 & 15.6 & $2.63(1.62-4.28)$ & $<0.001$ \\
\hline No & 3,098 & 97.0 & 5.9 & 1.00 & \\
\hline \multicolumn{6}{|l|}{ Serious accident } \\
\hline Yes & 73 & 2.3 & 15.1 & $2.50(1.43-4.39)$ & 0.001 \\
\hline No & 3,121 & 97.7 & 6.0 & 1.00 & \\
\hline
\end{tabular}

95\% Cl: 95\% confidence interval.

* Unknown for $2.2 \%$ : loss of interview with housewife;

** $12.8 \%$ unknown;

*** Monthly minimum wage: R\$120.00 (US\$ 105.00), July 1998;

\# Passing school grades;

\#\# In some family member living in the household;

\#\#\# Linear trend. 
mon-law unions (76\%) (Table 2). In $91 \%$ of the cases, the housewife was the mother of the child in the interview.

Unemployment was the most frequent family problem, since in $18 \%$ of the households at least one person was currently out of work or had been unemployed in the previous year. Alcohol abuse and illicit drug use, and the presence of a chronically ill family member requiring constant care by the household residents, occurred in approximately $10 \%$ of the families. Some $5 \%$ of the homes had experienced separation/divorce of a couple, death, or financial difficulties such as major indebtedness or bankruptcy. Less frequent family problems included single motherhood (3\%) and serious accidents (2\%) (Table 2).

Crude analysis of the effect of family characteristics on children's smoking showed no association with the following family problems: chronically ill family members requiring care and death of a family member. The other variables were included in the multivariate analysis, since childhood smoking was associated with low family income and low housewife's schooling, absence of the housewife's spouse or partner, and the following family problems: unemployment, alcohol abuse and illicit drug use, separation/divorce, serious indebtedness or bankruptcy, and serious accidents (Table 2).

Table 3 shows the multivariate analysis. The effect of child labor on children's smoking persisted after adjusting for the children's and families' characteristics, and working children showed $75 \%$ greater likelihood of being smokers.

Smoking prevalence was higher among working children, whatever the kind of work, as compared to their non-working peers. However, among the working children, no differences in smoking prevalence were observed according to the kind of work.

Family income did not remain associated with childhood smoking after adjusting for the housewife's schooling and marital status. Meanwhile, higher maternal schooling was a protective factor has the smoking habit in children, showing a significant linear trend. Children in homes where the housewife had more schooling ( $>8$ years) showed a lower risk of smoking, when compared to those with no schooling. When the housewife did not live with a spouse or partner, there was an $18 \%$ greater likelihood of the child being a smoker. Age was an important risk factor for childhood smoking, with a twofold prevalence among older children (16 and 17 years).

Children with a history in the previous year of household members with alcohol abuse or illicit drug use, single motherhood, or serious accidents showed higher smoking prevalence rates, when compared to those without such household crisis situations, with prevalence ratios of 1.63, 1.93, and 2.22 respectively. The effects of other family problems (unemployment, separation/divorce, and major indebtedness or bankruptcy) lost their statistical significance after adjustment (Table 3).

Inadequate grade-for-age in the child was the variable showing the strongest association with smoking (six-fold odds). Children with aggressive/delinquent type behavior problems showed higher smoking prevalence, but the same was not true for those with internalizing behavior. Smoking prevalence was $67 \%$ higher among children with externalizing behavior (Table 3).

\section{Discussion}

This study's findings showed that child labor was associated with smoking in children and adolescents, maintaining its effect after adjusting for the children's and their families' characteristics. This observation is unprecedented in Brazilian studies and is consistent with studies in other countries, where smoking is more frequent among working teens $14,16,30$. Although this is a study on associations, smoking prevalence $(6.3 \%$ in the 10 to 17 year age bracket) was considered high, since this is a preventable exposure with proven harm to health, high addictive potential, and particularly worrisome when it affects such a young population.

The majority of studies on childhood smoking are school-based, thus tending to underestimate the prevalence rates for this outcome and other exposures as compared to the general population. This study's sample was householdbased, thus allowing an analysis of all the children, including those not attending school. The small number of losses also tends to reinforce the findings' reliability.

An analysis of the study's results deserves consideration of some methodological aspects. The sample selection excluded census tracts with the highest mean income levels, but this exclusion did not jeopardize the analysis of potential associations. In the selection base, good representativeness was maintained for the more economically privileged tracts, since nearly onethird of the families had incomes greater than or equal to six times the monthly minimum wage, thus allowing the analysis of associations between childhood smoking and socioeconomic factors. Another relevant issue is the probable low precision in measuring family problems such as alcohol abuse, illicit drug use, and serious accidents, with a tendency to underesti- 
Hierarchical multivariate Poisson regression analysis for childhood smoking, according to the children's and families' characteristics. Pelotas, Rio Grande do Sul State, Brazil $(N=3,269)$.

\begin{tabular}{|c|c|c|}
\hline Characteristics & Adjusted PR * $(95 \% \mathrm{Cl})$ & $\mathrm{p}$-value \\
\hline \multicolumn{3}{|l|}{ 1st level: socioeconomic and child's age } \\
\hline 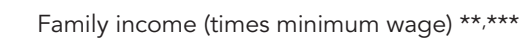 & & $0.9 \#$ \\
\hline$\leq 1.0$ & 1.00 & \\
\hline $1.1-2.0$ & $0.98(0.58-1.68)$ & \\
\hline 2.1-4.0 & $0.94(0.58-1.54)$ & \\
\hline $4.1-6.0$ & $1.00(0.57-1.48)$ & \\
\hline$>6.0$ & $1.00(0.57-1.78)$ & \\
\hline Housewife's schooling (years) & & $0.006 \#$ \\
\hline None & 1.00 & \\
\hline $1-4$ & $0.88(0.52-1.48)$ & \\
\hline $5-8$ & $0.66(0.39-1.13)$ & \\
\hline$\geq 9$ & $0.47(0.24-0.91)$ & \\
\hline \multicolumn{3}{|l|}{ Housewife's marital status } \\
\hline With husband/partner & 1.00 & \\
\hline Without husband/partner & $1.18(1.09-1.28)$ & $<0.001$ \\
\hline \multicolumn{3}{|l|}{ Child's age (years) } \\
\hline $10-15$ & 1.00 & \\
\hline $16-17$ & $2.14(1.87-2.45)$ & $<0.001$ \\
\hline \multicolumn{3}{|l|}{ 2nd level: family problems } \\
\hline \multicolumn{3}{|l|}{ Unemployment } \\
\hline Yes & $1.20(0.88-1.63)$ & 0.2 \\
\hline No & 1.00 & \\
\hline \multicolumn{3}{|l|}{ Alcohol or drugs } \\
\hline Yes & $1.63(1.16-2.28)$ & 0.004 \\
\hline No & 1.00 & \\
\hline \multicolumn{3}{|l|}{ Separation/Divorce } \\
\hline Yes & $1.09(0.71-1.68)$ & 0.7 \\
\hline No & 1.00 & \\
\hline \multicolumn{3}{|l|}{ Major indebtedness or bankruptcy } \\
\hline Yes & $1.31(0.79-2.18)$ & 0.3 \\
\hline No & 1.00 & \\
\hline \multicolumn{3}{|l|}{ Single mother } \\
\hline Yes & $1.93(1.23-3.02)$ & 0.004 \\
\hline No & 1.00 & \\
\hline \multicolumn{3}{|l|}{ Serious accident } \\
\hline Yes & $2.22(1.35-3.66)$ & 0.002 \\
\hline No & 1.00 & \\
\hline \multicolumn{3}{|l|}{ 3rd level: child's schooling } \\
\hline \multicolumn{3}{|l|}{ Adequate grade-for-age } \\
\hline Yes & 1.00 & $<0.001$ \\
\hline No & $6.05(3.62-10.09)$ & \\
\hline \multicolumn{3}{|l|}{ 4th level: behavior and work } \\
\hline \multicolumn{3}{|l|}{ Internalizing behavior } \\
\hline Yes & $0.92(0.68-1.25)$ & 0.6 \\
\hline No & 1.00 & \\
\hline
\end{tabular}

(continues) 


\begin{tabular}{lcc} 
Table 3 (continued) & Adjusted PR * $(95 \% \mathrm{Cl})$ & p-value \\
\hline Characteristics & & 0.001 \\
\hline Externalizing behavior & $1.67(1.24-2.24)$ & 1.00 \\
Yes & & $<0.001$ \\
No & $1.75(1.30-2.36)$ & 1.00
\end{tabular}

95\% Cl: 95\% confidence interval; PR: prevalence ratio.

* Adjusted for variables from the same level or higher;

** $12.8 \%$ unknown;

*** Monthly minimum wage: $\mathrm{R} \$ 120.00$ (U\$105.00, in July 1998);

\# Linear trend.

mate prevalence rates and risks. However, these showed an association with smoking, consistent with the literature showing that young people living in conflictive family situations (alcohol abuse, broken homes, single mothers) are more prone to smoking 18 .

The study highlights the inverse association between schooling (for both children and their mothers) and smoking. Among children, inadequate grade-for-age and school non-attendance showed the strongest association with smoking, increasing the smoking prevalence rates by six and eight times, respectively. These findings are consistent with the literature 15,18. Meanwhile, for mothers there was an inverse and linear association between their schooling and their children's smoking, corroborating Menezes et al. 7. Maternal schooling stands out among socioeconomic factors with a positive impact on children's health, the development of healthy behaviors and habits, and better care for the children's health. For example, there is evidence that each additional year of maternal schooling is associated with a $4 \%$ increase in the use of preventive health services in the first year of children's lives. Children of mothers with no schooling have 1.2 to 2.8 times greater odds of being malnourished as compared to those of mothers with more schooling 36 .

The approach to this theme is enriched by the evaluation of child behavior in a comprehensive sample, not limited to schoolchildren or delinquent minors as in most of the literature, and using an instrument that makes a more detailed evaluation and with good sensitivity and specificity. The association between externalizing child behavior and smoking agrees with findings on children in the United States. Wu et al. 16, using the Youth Self-Report Checklist, showed that smoking is more frequent among children with externalizing behavior $(\mathrm{PR}=3.3$ and 4.2 for boys and girls, respectively, $\mathrm{p}<0.001$ ). This association also holds true for heavy smoking ( $>$ 20 cigarettes/day in the previous 30 days; $\mathrm{PR}=$ 3.1 and 6.8 for boys and girls, respectively). This instrument was developed by the same authors as the CBCL, using the same classification criteria, but with the child as the informant (12 to 17 years of age).

The principal target association compares two variables (work and smoking) that have in common a possible self-ascribed maturity, that is, both work and smoking may be viewed by the young person as essentially adult characteristics. Young people with a personality profile that leads them to seek rebellious behavior and transgression, partially inherent to this age bracket, may be the same ones who seek habits and attitudes associated with the independence of adulthood, like working. In order to shed light on these situations, we measure the effect of work independently from that of behavior, analyzing the latter as a possible confounding factor. We thus observed that the association between child labor and smoking remained even after adjusting for externalizing behavior. However, due to the study's cross-sectional design, the temporal sequence of these associations is not clear. Caution should thus be exercised when interpreting the association between child labor and smoking. In this sense, smoking may be both a consequence of schooling and child labor and a marker for behavior that has an impact on various dimensions in the lives of children and adolescents. At any rate, the higher rate of smoking among working youth is a reality, showing that children and adolescents are an important target public for smoking prevention.

Therefore, the current study, in addition to examining risk factors that have been approached 
by other authors, shows an important association between child labor and smoking, independently of externalizing behavior. The analysis also shows interesting results by detecting specificities in the determination of smoking according to the type of behavior. Children that are most prone to cigarette addiction are those with externalizing behavior, unlike those with internalizing behavior.

The study's findings suggest two health protection warnings in this phase of life: first, smoking as a potential source of harm to be included in the consequences of child labor. Next, that the workplace is a prime site for preventing and eliminating cigarette addiction. It is necessary to clarify that this sample includes two distinct groups of children and adolescents, due to their work status, and this consequently defines different action strategies for smoking prevention: the younger group (10 to 15 years), who are definitely in an illegal situation, since work is officially prohibited in this age bracket according to Brazil's Statute for Children and Adolescents. These younger children should be relieved from working, the more urgently so in cases of hazardous work. The increased risk of smoking is one further indicator reinforcing this necessity. Meanwhile, the older group, 16 and 17 years of age, are legally allowed to work, except in cases

\section{Resumo}

Este estudo transversal avaliou a associação entre o tabagismo e o trabalho de crianças e adolescentes, através de análise multivariada hierárquica por regressão de Poisson. Foram entrevistados, em seus domicílios, 3.269 jovens (10 a 17 anos), da população urbana de Pelotas, Rio Grande do Sul, Brasil (excluídas áreas de maior renda), em 1998. A prevalência de trabalho infantil foi 13,8\%. As prevalências de tabagismo atual foram 6,3\% na amostra, 15,7\% entre trabalhadores $e$ $3,4 \%$ entre não trabalhadores. Após o ajuste para fatores de confusão, o tabagismo manteve-se associado ao trabalho infantil com razão de prevalência de 1,75 (IC95\%: 1,30-2,36). O tabagismo manteve-se associado a características da família (menor escolaridade da dona da casa, ausência de seu companheiro, problemas como uso de álcool ou drogas, mãe solteira e acidente grave) e da criança (idade $>16$ anos, escolaridade inadequada para idade e comportamento agressivo). Os resultados apontam o tabagismo como um dano a ser incluído nas conseqüências do trabalho infantile indicam o trabalho como local para sua prevenção.

Trabalho de Menores; Tabagismo; Criança; Adolescente of hazardous work and/or night shifts. For this group, preventive and support measures should focus on smoking cessation.

The definition of the best strategies for smoking prevention and cessation should take into consideration that societies and governments are ambivalent toward smoking: on the one hand they condemn it as the cause of serious illness and death, while on the other they appreciate the economic activity and tax revenue it produces. Brazil is a good example of this contradiction, as the world's largest exporter of tobacco leaves, the second largest producer of tobacco leaves ${ }^{3}$, and the sixth largest cigarette market 37 . Meanwhile, the country has conducted an effective public health program for tobacco control. Early smoking initiation does not occur by chance; on the contrary, it results from powerful action by the tobacco industry in recruiting new consumers, mostly adolescents 1 . Unfortunately, what often begins as a quest for independence can rapidly turn into tobacco addiction 38 . At the same time, early participation in work, besides constituting a form of exploitation of cheap, vulnerable labor, can also lead to serious health problems. By identifying the association between child labor and smoking, the current study emphasizes the potential health risks of early work.

\section{Contributors}

M. M. Dall'Agnol and A. G. Fassa participated in the design, fieldwork, analysis, and writing of the article. L. A. Facchini collaborated in the design, fieldwork, and analysis of the final article.

\section{Acknowledgments}

The authors wish to thank the National Research Council (CNPq) and the Pan-American Health Organization (PAHO) for funding the research. 


\section{References}

1. World Health Organization. Growing up without tobacco: World No-Tobacco Day 1998. Geneva: World Health Organization; 1998.

2. Warren CW, Jones NR, Peruga A, Chauvin J, Baptiste J-P, Costa de Silva V, et al. Global youth tobacco surveillance, 2000-2007. MMWR Surveill Summ 2008; 57:1-28.

3. Shafey O, Eriksen M, Ross A, Macka J. The Tobacco Atlas. 3rd Ed. Atlanta: American Cancer Society; 2009.

4. U.S. Department of Health and Human Services. The health consequences of smoking: a report of the surgeon general. Atlanta: U.S. Department of Health and Human Services; 2004.

5. U.S. Department of Health and Human Services. Preventing tobacco use among young people: a report of the surgeon general. Atlanta: U.S. Department of Health and Human Services; 1994.

6. Pan American Health Organization. Youth and tobacco in Latin America and the Caribbean: results from the Global Youth Tobacco Survey. www.paho. org/English/AD/SDE/RA/emtj_eng_06062006.pdf (accessed on 30/Jan/2010).

7. Menezes AMB, Minten GC, Hallal PC, Victora CG, Horta BL, Gigante DP, et al. Tabagismo na coorte de nascimentos de 1982: da adolescência à vida adulta, Pelotas, RS. Rev Saúde Pública 2008; 42: 78-85.

8. Monteiro CA, Cavalcante TM, Moura EC, Claro RM, Szwarcwald CL. Population-based evidence of a strong decline in the prevalence of smokers in Brazil (1989-2003). Bull World Health Organ 2007; 85:527-34

9. Amos A, Wiltshire S, Haw S, McNeill A. Ambivalence and uncertainty: experiences of and attitudes towards addiction and smoking cessation in the mid-to-late teens. Health Educ Res 2006; 21:181-91.

10. Turner L, Mermelstein R, Flay B. Individual and contextual influences on adolescent smoking. Ann N Y Acad Sci 2004; 1021:175-97.

11. Global Youth Tobacco Survey Collaborative Group. Tobacco use among youth: a cross-country comparison. Tob Control 2002; 11:252-70.

12. Hallal ALLC. Fatores associados ao tabagismo em escolares [PhD Dissertation]. São Paulo: Faculdade de Saúde Pública, Universidade de São Paulo; 2008.

13. Almeida LM, Cavalcante TM, Casado L, Fernandes EM, Warren CW, Peruga A, et al. Linking Global Youth Tobacco Survey (GYTS) data to the WHO Framework Convention on Tobacco Control (FCTC): the case for Brazil. Prev Med 2008; 47 Suppl 1:S4-10.

14. Carriere G. Weekly work hours and health-related behaviours in full-time students. Health Rep 2005; 16:11-22.

15. Malcon MC, Menezes AMB, Maia MFS, Chatkin M, Victora CG. Prevalência e fatores de risco para tabagismo em adolescentes na América do Sul: uma revisão sistemática da literatura. Rev Panam Salud Pública 2003; 13:222-8.
16. Wu LT, Schlenger WE, Galvin DM. The relationship between employment and substance use among students aged 12 to 17 . J Adolesc Health 2003; 32: 5-15.

17. Silva MAM, Rivera IR, Carvalho ACC, Guerra Júnior AH, Moreira TCA. Prevalência e variáveis associadas ao hábito de fumar em crianças e adolescentes. J Pediatr (Rio J.) 2006; 82:365-70.

18. Horta BL, Calheiros P, Pinheiro RT, Tomasi E, Amaral KC. Tabagismo em adolescentes de área urbana na Região Sul do Brasil. Rev Saúde Pública 2001; 35:159-64.

19. Pinto D, Ribeiro SA. Variáveis relacionadas à iniciação do tabagismo entre estudantes do ensino médio de escola pública e particular na cidade de Belém - PA. J Bras Pneumol 2007; 33:558-64.

20. Machado Neto AS, Cruz AA. Tabagismo em amostra de adolescentes escolares de Salvador-Bahia. J Pneumol 2003; 29:264-72.

21. Menezes AMB, Hallal PC, Horta BL. Early determinants of smoking in adolescence: a prospective birth cohort study. Cad Saúde Pública 2007; 23:347-54.

22. Silva MP, Silva RM, Botelho C. Factors associated with cigarette experimentation among adolescents. J Bras Pneumol 2008; 34:927-35.

23. Menezes AMB, Gonçalves H, Anselmi L, Hallal PC, Araújo CL. Smoking in early adolescence: evidence from the 1993 Pelotas (Brazil) Birth Cohort Study. J Adolesc Health 2006; 39:669-77.

24. Vieira PC, Aerts DRGC, Freddo SL, Bittencourt A, Monteiro L. Uso de álcool, tabaco e outras drogas por adolescentes escolares em município do Sul do Brasil. Cad Saúde Pública 2008; 24:2487-98.

25. Malcon MC, Menezes AMB, Chatkin M. Prevalência e fatores de risco para tabagismo em adolescentes: estudo de base populacional, no sul do Brasil. Rev Saúde Pública 2003; 37:1-7.

26. Institute of Medicine. Protecting youth at work: health, safety, and development of working children and adolescents in the United States. Washington DC: National Academy Press; 1998.

27. Chong J, Ingram M, McClelland DJ, Lopez DC, De Zapien JG. Smoking behavior in a smoking workplace. J Subst Abuse 2000; 11:231-40.

28. Smith D, Leggat P. Tobacco smoking by occupation in Australia: results from 2004 to 2005 National Health Survey. J Occup Environ Med 2007; 49: 437-45.

29. Mortimer JF, Ryu S, Shanahan MJ, Call KT. The effect of work intensity on adolescent mental health achievement, and behavioral adjustment: new evidence from a prospective study. Child Dev 1996; 67:1243-61.

30. Wakai K, Miura H, Umenai T. Effect of working status on tobacco, alcohol, and drug use among adolescents in an urban area of Thailand. Addict Behav 2005; 30:457-64.

31 Instituto Brasileiro de Geografia e Estatística. Síntese de indicadores sociais 2005. Rio de Janeiro: Instituto Brasileiro de Geografia e Estatística; 2005. 
32. International Labor Organization. The end of child labour: within reach. Geneva: International Labor Organization; 2006.

33. Instituto Brasileiro de Geografia e Estatística. Censo demográfico 1991. Rio de Janeiro: Instituto Brasileiro de Geografia e Estatística; 1992.

34. Achenbach TM. Manual for the child behavior checklist/4-18 and 1991 profile. Burlington: Department of Psychiatry, University of Vermont; 1991.

35. Bordin IAS, Mari JJ, Caeiro MF. Validação da versão brasileira do "Child Behavior Checklist" (CBCL) (Inventário de Comportamentos da Infância e Adolescência): dados preliminares. Revista ABPAPAL 1995; 17:55-66.
36. Fassa AG. Health benefits of eliminating child labour. Geneva: International Labor Organization; 2003.

37. World Health Organization. Tobacco or health in Brazil. Geneva: World Health Organization; 1998.

38. World Health Organization. Tobacco use by children: a pediatric disease. Geneva: World Health Organization; 1998.

Submitted on 30/Jun/2009

Final version resubmitted on $05 / \mathrm{Feb} / 2010$

Approved on 01/Apr/2010 